\title{
Paul A. Ebert, MD
}

\author{
Constantine Mavroudis, MD
}

Paul Allen Ebert, MD, the 68th President of the American Association for Thoracic Surgery, died in the early hours of April 21, 2009, in Sacramento, California, quite unexpectedly of an acute myocardial infarction at 76 years of age. He was a towering figure of a man, a virtual giant upon whose shoulders stood a generation of trainees, colleagues, admirers, sports fans, philosophers, friends, and family members. He could have done anything, it seemed, which made his premature passing all the more poignant and stark.

Paul Ebert was one of those gifted persons who excelled in everything that he did. As a student at The Ohio State University, he was a forward and center on the school's basketball team and a pitcher on the baseball team. In basketball he was first team All Big Ten and team MVP every year that he played at Ohio State, which culminated in All American honors as a senior. In baseball he had a career 21-8 record, leading his team in strikeouts and wins every year that he played, which earned him consensus All American selection in his senior year. Opportunities to play professional baseball were put aside for loftier goals.

Paul Ebert enrolled at The Ohio State University Medical School, during which time he married his high school sweetheart, Louise Joyce Parks, on September 4, 1954. Together, they were to share the next 55 years in constant companionship, parenthood, grandparenthood, and adopted family of their numerous trainees. Dr Ebert graduated from Ohio State University Medical School in 1958. Dr Robert Zollinger, the Chair of Surgery at the time, recommended Paul to Dr Alfred Blalock of Johns Hopkins University, where he excelled in a program that was to foster some of the great surgeons and educators of the 20th century. After 2 years as a senior assistant surgeon at the National Heart Institute, he became professor of surgery at Duke University, where Dr David Sabiston was establishing his now-famous residency training program. Dr Ebert's stature as a surgeon and virtuous individual grew very quickly. He served as chairman of the Department of Surgery at Cornell University Medical Center during the years 1971 to 1975 . From 1975 to 1986 , he was chairman at the University of California San Francisco. In 1986, he assumed the directorship of the American College of Surgeons until his retirement in 1998.

\footnotetext{
From the Department of Pediatric and Congenital Heart Surgery, Cleveland Clinic, Cleveland Clinic Lerner School of Medicine, Case Western Reserve University, Cleveland, Ohio.

Address for reprints: Constantine Mavroudis, MD, Cleveland Clinic Children's Hospital, Center for Pediatric and Adult Congenital Heart Disease, 9500 Euclid Ave, M41-02, Cleveland, OH 44195 (E-mail: mavrouc@ccf.org).

J Thorac Cardiovasc Surg 2009;138:273-4

$0022-5223 / \$ 36.00$

Copyright (c) 2009 by The American Association for Thoracic Surgery doi:10.1016/j.jtcvs.2009.05.025
}

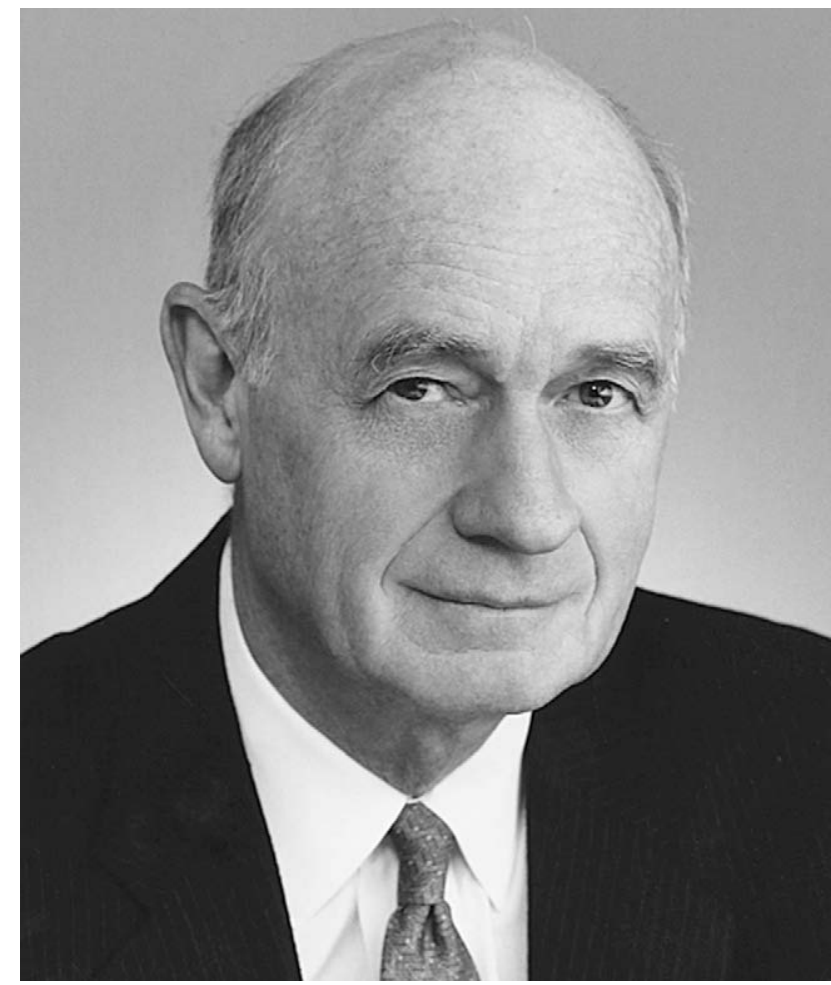

Some of his most important contributions to surgery were the initial experiments that introduced cardioplegia to clinical cardiothoracic surgery, neonatal and infant cardiac surgery, development of clinical techniques that dramatically improved survival for patients with truncus arteriosus, and establishment of the pioneering techniques that led to neonatal application of the arterial switch operation for transposition of the great arteries. His 198 manuscripts in peer-reviewed journals are a record of achievement that speaks for his genius and innovative talents.

He was a masterful teacher whose efforts in the operating room were aimed at making sure that the trainee could perform the operation without his help. The result of this teaching style has been demonstrated by the success of his trainees and, subsequently, by the success of their trainees. There can be no greater testimony to his memory than the living manifestation of his methods learned by generations to come.

Paul Ebert touched a generation of colleagues, students, and patients from all parts of the world. One was struck immediately by his humanity, character, and stature. He was gentle and polite but not at the cost of a spiritless, weakwilled posture. He could argue effectively, but in the end, 
no matter what the outcome, the experience was fruitful, engaging, and educational. It was amazing that one with so many strong ideas and committed visions could be loved by so many. Perhaps his most noble of traits was that he could "get out of himself" to recognize the needs and concerns of others. He was a very unselfish man.

Besides serving as president of the American Association for Thoracic Surgery, Dr Ebert was elected president of the American College of Cardiology, the Association of Academic Surgery, the Society of University Surgeons, and the Western Thoracic Surgical Association. In 1989, he was the recipient of the Theodore Roosevelt Award, the highest honor that the National Collegiate Athletic Association can confer on an individual, awarded to a distinguished citizen of national reputation based on outstanding life achievement. Some other awardees have been Dwight Eisenhower, Jesse Owens, George H. W. Bush, Ronald Reagan, and Denton Cooley.
Everyone loved to talk to Paul, especially about sports. It was easy to see why he was such an accomplished surgeon; he had the hand-eye coordination of a 2-sport All American. He did not have a favorite pitch in baseball or a preferential shot in basketball. He could beat the opposing team with whatever pitch or shot was necessary. He was just a natural, the likes of which will not come again soon. He is survived by Louise Joyce Parks, his wife of 55 years; his children, Leslie Ebert Buhlman, Michael Ebert, and Julie EbertMcQuillan; and his grandchildren, Holly, Rudy, Claire, and Paul Buhlman and Danyon Ebert-McQuillan.

In the end, history will remember Paul Ebert for the Renaissance man that he was: scholar, quintessential surgeon, investigator, athlete of legendary proportions, and committed teacher. His family will remember him for his love, affection, candor, and unconditional devotion. Those who worked with him will remember his virtues, humanity, humor, and sensitivity. We will all miss him. 